\title{
NEOPLEISTOCENE DEPOSITS IN THE KOLA REGION: STRATIGRAPHY AND THE KEY-SECTIONS - A CONTRIBUTION TO THE DATABASE OF THE QUATERNARY TERRESTRIAL EUROPEAN STRATIGRAPHY (DATESTRA)
}

\section{Korsakova O.P.}

\section{Geological Institute of KSC RAS, Anamumbl,korsak@geoksc.apatity.ru}

In recent years, the Neopleistocene stratigraphy arouses interest in the context of the DATESTRA Project (Database of Terrestrial European Stratigraphy) [6], which has been supported by INQUA. Neopleistocene deposits in the Kola region have accumulated under conditions of recurrent glaciations and the following interglacial warming with marine transgressions, which appeared here in the coastal areas. The interglacial-glacial cyclicity offers an opportunity to apply climatostratigraphic methods for subdivision of corresponding deposits. Accompanied by biostragraphic and geochronometrical methods, this approach enables definition and correlation of short-term (about tens of thousands years) stratigraphic units. Using this approach, middle and the upper Neopleistocene units have been identified in the sediment successions in the Kola Region. The aim of this paper is to review the available data (published mainly in Russian), which are applicable to the Database of Terrestrial European Stratigraphy.

\section{Material and methods}

A review of the available data includes only the key-sections with stratigraphic units that were identified according to lithological, palaeontological (pollen, diatoms, foraminifera and others) features and geochronometrically $\left(\mathrm{C}^{14}, \mathrm{U}-\mathrm{Tr}, \mathrm{ESR}, \mathrm{IR}-\mathrm{OSL}\right)$ dated. The data have to be published in scientific papers or books that are accessible to the public. Fig. 1 shows 10 key-points that have been taken into account [1-5, 7-14]. All stratigraphic units correlate with the marine isotope stages (MIS).

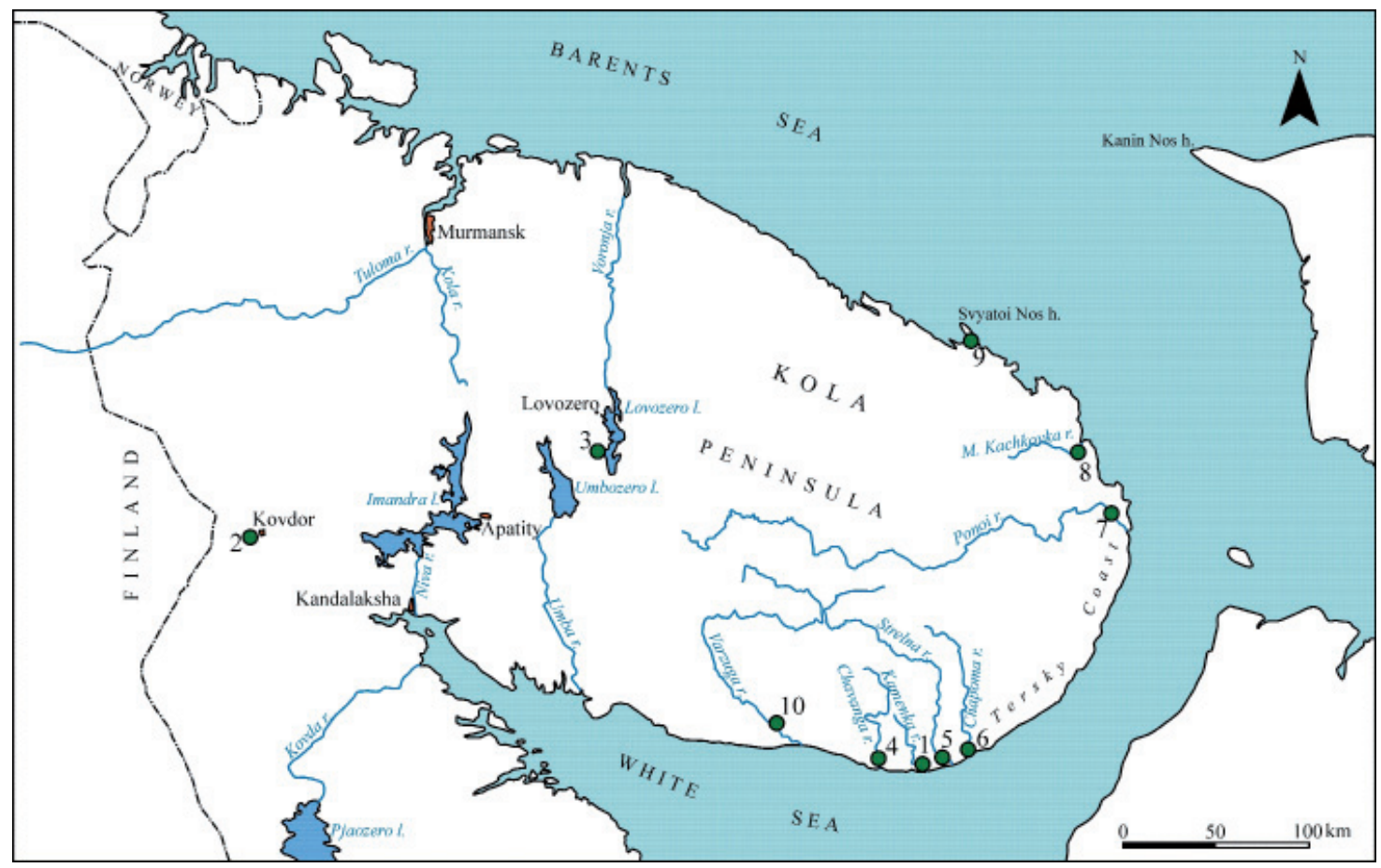

Fig. 1. Location of the middle and late Neopleistocene key-sections in the Kola region.

The key localities are shown by Arabic numerals: 1 - the right bank of the Kamenka River valley, 2 - the western outskirts of the town of Kovdor, 3 - Seidozero-Lovozero height of land, East of the Lovozero Tundra mountain mass, 4 - the right bank of the Chavanga River valley, 5 - the right bank of the Strelna River valley, 6 - the left bank of the Chapoma River valley, 7 - the left bank of the Ponoi River valley, 8 - the upper reach of the left tributary of the Malaya Kachkovka River, 9 - the head of the Svyatoi Nos Bay, Barents Sea, 10 - right bank of the Varzuga River valley. 
According to the current Quaternary System subdivisions for European Russia [15], the upper Neopleistocene includes Mikulinsky (MIS 5), Podporozhsky (MIS 4), Leningradsky (MIS 3), and Ostashkovsky (MIS 2) Horizons; middle Neopleistocene associates with Likhvinsky (MIS 11), Kaluzhsky (MIS 10), Chekalinsky (MIS 9), Vologodsky (MIS 8), and Gorkinsky (MIS 7) Horizons.

\section{Middle Neopleistocene key-sections}

The available data from the Kola Peninsula evidence the Neopleistocene (the middle and late Pleistocene in West Europe) stratigraphy record begins here with the Chekalinsky (MIS 9) Horizon $[10,11]$. The most ancient deposits are known from only one locality. The corresponding unique keysection is situated in the southern Kola Peninsula on the right bank of the Lower Varzuga River (10 in Fig. 1). The basal part of the Varzuga section is represented by superposition of consolidated clay, loam, sandy loam with subfossil mollusc shells ESR dated between 319 and $316 \mathrm{ka}$, and lenses of coarse-grained sand, and pebbles. Recurring vegetative assemblages are characterized by increasing quantity of Betula sect. Albae with occurrence of mesophilous and thermophilous components (Alnus, Quercus, Tilia, Ulmus, Carpinus, Corylus, Osmunda, Nuphar, Nymphaea) indicate several middle Neopleistocene warm climatic events. The middle Neopleistocene Checalinsky (MIS 9), Vologodsky (MIS 8), and Gorkinsky (MIS 7) Horizons are probably presented in the Varzuga key-section.

In the interglacial marine clay sediments exposed in the Varzuga outcrop, Knipowich and Lavrova [12] found 24 mollusc species; $25 \%$ are boreal and mainly boreal species, with Dentalium entalis L., Mytilus edulis L., Panopaea norvegica (Spengl), which currently do not inhabit the White Sea; $46 \%$ are arcticboreal species, 29\% - arctic ones [3, 9]. Diatoms are represented by polygalobs, methogalobs, oligogalobs (galophils, indifferents). Twenty three foraminifera species with dominating boreal-arctic Cribroelphidium goesi (Stshedr.) and warm-water Cassidulina subacuta (Gud.), Elphidium aff. subclavatum, Islandiella islandica (Norv.), Asrtononion gallowayi Loebl. et Tappan ones were identified. Some cold-water species (Buccella frigida (Cushm.), Nonionellina labradorica (Dawson), Protelphidium orbiculare (Brady), Cribroelphidium goesi (Stshedr.) were also found [3].

Till and melt-water deposits of the Moskovsky (MIS 6) Horizon are known in numerous outcrops from the western and central parts of the Kola region, and on the White Sea coast. Four key-sections are situated in the head of the Svyatoi Nos Bay of the Barents Sea (9 in Fig. 1), in the valleys of the Lower Chapoma (6 in Fig. 1), Ponoi (7 in Fig. 1), and Malaya Kachkovka (8 in Fig. 1) Rivers. Moskowsky Horizon deposits are overlaid here by interglacial sediments attributed to the Mikulinsky (MIS 5) Horizon.

\section{Late Neopleistocene key-sections}

In the current Russia Quaternary System subdivisions, the interglacial Mikulinsky (MIS 5) Horizon correlates to the NW European Eemian (MIS 5e) subdivision and the lower Weichselian (MIS 5a-d) one [15]. Generally represented by marine and brackish-water sediments, the Mikulinsky Horizon includes both the Ponoi and Strelna Beds identified in the Kola upper Neopleistocene Stratirgaphy. The ESR/OSL-age of the Ponoi and Strelna Beds ranges from approximately 120 - 130 to 100 - $105 \mathrm{ka}$ (MIS 5e-d) and $100-105$ to $70-80 \mathrm{ka}$ (MIS 5c-a), respectively [7,9]. The key-section with the Ponoi and Strelna Beds is situated in the valleys of the Strelna (5 in Fig. 1), Chapoma (6 in Fig. 1), Ponoi (7 in Fig. 1), and Malaya Kachkovka (8 in Fig. 1) Rivers and in the head of the Svyatoi Nos Bay, Barents Sea (9 in Fig. 1). Palynological proxies and diatom data from the Ponoi Beds indicate a more favorable environment as compared with the modern one [1-5, 7-14]. Palaeontological remains enclosed in the Strelna Bed sediments indicate environment conditions close to the modern ones or colder [3,12].

The interglacial Mikulinsky lacustrine sediments and peat were drilled on the slopes of the Lovozero Tundra (5 in Fig. 1) in the central part of the Kola region [4]. Interglacial deposits are overlaid here by till (MIS 4?) and lacustrine sand (MIS 3?).

Glacial deposits of the Podporozhsky (MIS 4) Horizon are known from the central, north-western, western, and southern parts of the Kola region [2, 4, 7-10]. Natural exposures with the Podporozhian deposits have been found on the Tersky Coast of the White Sea, represented by till, probably glaciomarine sandy loam and sand, glaciofluvial and glaciolacustrine sand and sandy loam in the outcrops. As key- 
sections we can only take into account the depositional successions from the Kamenka (1 in Fig. 1) and Chavanga (4 in Fig. 1) River valleys [7, 9], and from the Seidozero-Lovozero height of land (3 in Fig. 1); the Podporozhsky Horizon has the lower stratigraphic boundary here. The upper boundary is identified in the Kamenka sedimentary succession (1 in Fig. 1); the glaciolacustrine sand here was IR-OSL-dated at $63.6 \pm 8.0$ [9].

Interstadial peat and lacustrine and fluvial sand of the Leningradsky (MIS 3) Horizon are known from the Kovdor open pit (2 in Fig. 1) in the western Kola region, from boreholes in the Lovozero Tundra Mountains (3 in Fig. 1) [2, 14], and from the Kamenka sedimentological succession (1 in Fig. 1) [7, 9]. Providing a record of Valdaian (middle and late Weichselian in western Europe) marine and glacial sedimentation, the key-section in the Kamenka River valley is the most informative. Fragments and valves of shells of the arcto-boreal and arctic molluscan species, such as Chlamys islandicus Mll, Astarte crenata Gray, A. crenata var. crebricostata, Mya sp., and Pecten islandicus have been found here. Among diatoms, polygalobs, and sparse methogalobs, and oligogalobs species (Isthmia nervosa Ktr., Isthmia sp., Rhabdonema sp., Melosira sulcata (Her.) Ktz.)) have been identified; no thermophilic diatoms have been found here [4]. Scarce palaeontological data suggest littoral and sublittoral conditions of a rather cold sea reservoir. Spore and pollen data evidence the environment conditions were more severe than at the present time; terrestrial area was dominated by forest-tundra (Betula-Pinus sparse growth of trees) and tundra [3, 4, 14]. The ages of the sediments from the Kamenka section [9] and the Kovdor industrial open pit [14] were determined by ESR and ${ }^{14} \mathrm{C}$ dating of mollusc shells and humus between 31 and $59 \mathrm{ka}$.

Tills and melt-water sediments of the glacial Ostashkovsky (MIS 2) Horizon are the most common in the Kola region. Nevertheless, the corresponding key-sections or stratotypes have not been referred yet.

Acknowledgements. This is a contribution to the DATESTRA project. The work has partly been supported by CPbU-DFG 18.65.39.2017 project, RFBR (project no. 17-05-00706) and partially financed by Russian state budget as a branch of research project GI KSC RAS № 0231-2015-0010 (state registration № AAAA-A16-116022610099-7).

\section{References}

1. Arslanov K.A., Yevzerov V.Y., Tertichnyi N.I., Gerasimov S.A., Lokshin N.V. K voprosu o vozraste otlozhenii borealnoi transgressii (ponoiskikh sloev) na Kolskom poluostrove (On the age of deposits (Ponoi Beds) Boreal transgression in the Kola Peninsula). In: Pleistotsenovye oledeneniya Vostochno-Evropeiskoi ravniny (Pleistocene glaciations on the East European Plain). Moscow: Nauka, 1981. P. 28-37. (in Russian)

2. Astafiev B.Yu., Bogdanov Yu. B., Voinova O.A., Zhuravlev V.A., Nogina M.Yu., Paramonova M.S., Peshkova I.N., Polyakov A.A., Rybalko A.E., Solonina S.F., Semenova L.R., Surikov S.N., Sharov N.V., S.N., Shkarubo S.I. Gosudarstvennaya geologicheskaya karta Rossiyskoy Federatsii, Masshtab 1:1 000000 (tretie pokolenie). Seriya Baltiyskaia. List Q-37 - Arkhangelsk. Obiasnitelnaya zapiska (National Map of the Russian Federation, scale 1:1 000000 (third generation), Baltic series, Sheet Q-37 - Arkhangelsk. Explanatory Note). St. Petersburg: VSEGEI Press, 2012. 302 p. (in Russian).

3. Gudina V.I., Yevzerov V.Ya. The stratigraphy and foraminifera of the Upper Pleistocene in the Kola Peninsula. The British Library Board, 1981. (Translated by Lees, E., Edited by Hugnes, M).

4. Grave M.K, Yevzerov V.Ya., Likhachev A.B., Spicin A.G., Novye dannye o rykhlykh otlozheniyakh i formirovanii relief Seidozerskogo rayona (Lovozerskiye Tundry) (New data on detrital deposits and relief formation of Seydozero area (Lovozero Tundra)). In: Relief i geologicheskoe stroenie osadochnogo pokrova Kolskogo poluostrova (Relief and geological structure of the sedimentary cover of the Kola Peninsula. Moscow-Leningrad: Nauka Press, 1964. P. 5-47. (in Russian).

5. Grave M.K., Gunova V.S., Devyatova E.I., Lavrova M.A., Lebedeva R.M., Samsonova L.Ya., Cheremisinova E.A. Mikulinskoye mezhlednikov'ye na yugo-vostoke Kolskogo poluostrova (Mikulinian interglacial in the south-eastern Kola Peninsula). In: Osnovnye problemy geomorfologii i stratigrafii antropogena Kolskogo poluostrova (The main problems of Anthropogenic geomorphology and stratigraphy of the Kola Peninsula). Leningrad: Nauka Press, 1969. P. 25-56. (in Russian)

6. http://datestra-seqs.strikingly.com DATESTRA (Database of Quaternary Terrestrial European Stratigraphy). 
7. Korsakova O.P. Pleistocene marine deposits in the coastal areas of Kola Peninsula (Russia) // Quaternary International. 2009. V. 206. P. 3-15.

8. Korsakova O., Kolka V., Semenova L. Late Pleistocene stratigraphy according to the sediment sequence from eastern Kola Peninsula, Ponoi River Valley (North-Western Russia) // Quaternary International. 2016. V.420. P. 280-293.

9. Korsakova O.P., Molodkov A.N., Kolka V.V. Geological-stratigraphic position of Upper Pleistocene marine sediments in the Southern Kola Peninsula: evidence from geochronological and geological data // Doklady Earth Sciences. 2004. V. 398 (7). P. 908-912.

10. Korsakova, O.P., Semenova, L.R., Kolka, V.V. Sredne- and verkhneneopleistotsenovye osadki v razreze obnazheniya Varzuga (yug Kolskogo poluostrova) (Middle and upper Neopleistocene sediments in the sections from the Varzuga outcrop (southern Kola Peninsula)) // Regional Geology and Metallogeny. 2011. V. 48. P. 19-24. (in Russian)

11. Korsakova O, Yelovicheva Ya., Molodkov A, Kolka V. Middle Pleistocene marine deposits on the Kola Peninsula (NW Russia) // Quaternary International. (in press)

12. Lavrova M.A. Chetvertichnaya geologiya Kolskogo poluostrova (Quaternary geology of Kola Peninsula). Moscow-Leningrad: Academy of Sciences of USSR Press, 1960. (in Russian).

13. Nikonov A.A., Vostrukhina T.M. K stratigrafii antropogena severo-vostochnoy chasti Kolskogo poluostrova (On the Anthropocene stratigraphy in North-Eastern Kola Peninsula) // Doklady Akademii Nauk USSR. 1964. V. 158 (4). P. 104-107. (in Russian)

14. Yevzerov V.Ya, Koshechkin B.I. Paleogeografiya pleistotsena zapadnoy chasti Kolskogo poluostrova (Paleogeography of the western Kola Peninsula). Leningrad: Nauka Press, 1980. 105 pp. (in Russian)

15. Zastrozhnov, A.S. (Ed). Karta chetvertichnykh obrazovanyi territorii Rossiyskoi Federatsii. Masshtab 1:2500000 (A map of Quaternary deposits of the Russian Federation territory. Scale 1:2500000). Saint-Petersburg: All-Russian Geological Institute (VSEGEI) Press, 2014.http://www.vsegei.com/ru/info/quaternary-2500/ (in Russian). 